\title{
Creating win-wins in BC's forests... Taking on the sacred cows ${ }^{1}$
}

\author{
by Paul McElligott ${ }^{2}$
}

TimberWest Forest Corporation became Canada's only publicly traded private timberland investment vehicle in 1997 . In addition to private lands, the company holds two renewable Tree Farm Licenses and other public tenures. Revenues from logging represent $80 \%$ of the company's total revenue. The company has outperformed its industry peers in Canada and the United States. This success is attributed to the predominance of private lands in the company's business mix and to its ability to export logs off these lands. A case is presented for privatization of some, if not all, commercial forest land in British Columbia.

Key words: log exports, privatization, coastal forest industry, industry restructuring

TimberWest Forest Corporation est depuis 1997 l'unique véhicule public d'investissement dans des forêts privées au Canada. En plus des forêts privées, la compagnie détient deux concessions renouvelables et d'autres contrats d'aménagement publics. Les revenus de l'exploitation forestière représentent $80 \%$ des revenus totaux de la compagnie. La performance de la compagnie a excédé celle des entreprises comparables au Canada et aux Etats-Unis. Ce succès est attribué à la prédominance des terres privées dans le portefeuille d'affaires de la compagnie et à sa capacité d'exporter des billots à partir de ces terres. Une étude est présentée pour la privatisation de certaines, si ce n'est pas de toutes, des terres forestières commerciales en Colombie-Britannique.

Mots clés: exportation de billots, privatisation, industrie forestière côtière, restructuration de l'industrie

What I would like to do today is tell you a little bit about our company and then spend most of my time describing where the public land logging and sawmilling industry finds itself on the coast of $\mathrm{BC}$, how it got there, and what has to be done by whom to get it back on its feet. And I am going to talk about some sacred cows while going through this, including log exports and privatization of Crown lands.

\section{TimberWest Forest Corporation}

Our company became Canada's only publicly traded private timberland investment vehicle in 1997 . We own more than 800000 acres of fee-simple timberland, making us the largest private forest landowner in western Canada. We believe this land base, rich in Douglas fir and comprising $11 \%$ of the land mass on Vancouver Island, represents an outstanding basket of assets. We harvest some 2.3 million $\mathrm{m}^{3}$ of timber off these lands annually, and this harvest level is sustainable into perpetuity.

In addition to our private lands, we hold two renewable Tree Farm Licenses and other public tenures that enable us to harvest another 1.2 million $\mathrm{m}^{3}$ of Crown timber each year. We harvest timber in six different operating regions, all located on Vancouver Island.

We lead the coastal industry in mechanization and second growth harvesting on both public and private lands, with second growth representing more than $60 \%$ of our harvest.

Our company practises sustainable forest management and all our operations are certified by ISO and our private lands by the Sustainable Forestry Initiative. We have initiated many innovative stewardship activities, including a leading-edge watershed management strategy, an agreement with the Nature Conservancy to classify our lands to conserve portions with the highest ecological values, donation of time and resources to the recovery of the Vancouver Island marmot, and a terrestrial ecosys-

${ }^{1}$ Presentation to the Vancouver Board of Trade, April 4, 2003.

${ }^{2}$ President and CEO, TimberWest Forest Corporation, Vancouver, B.C. tem mapping program that allows us to identify sensitive ecosystems and determine where wildlife habitat exists so we can plan harvesting accordingly.

The other thing that makes us unique is that revenues from logging represent $80 \%$ of our company's total revenue. We operate a lumber mill at Campbell River that consumes about $800000 \mathrm{~m}^{3}$ of fibre each year. We directly employ some 1100

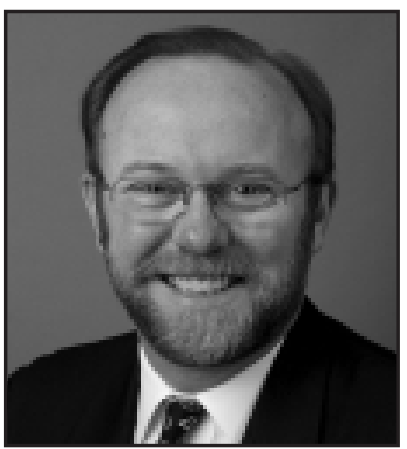

Paul McElligott people plus several hundred contractors. The company's annual revenue is approaching $\$ 500$ million and our market cap is almost \$1 billion.

Anyone keeping track of our performance since we went public will know that we have outperformed our industry peers in both Canada and the US. We attribute this to the predominance of private lands in our business mix and our ability to export logs off those lands, albeit with some restrictions. Despite difficult end markets and turbulence in the industry overall, TimberWest delivered a record year in 2002 because of cost cutting and growth in international sales.

Our market diversification program has been of particular importance to our track record. While there are federal restrictions on private land log exports requiring us to make logs available to domestic buyers first at reduced prices, when we do export $\operatorname{logs}$ there are considerable price premiums over domestic sales. In fact, in 2002, more than $50 \%$ of TimberWest's cash profits came from the price premium earned on the one-third of our harvest that found its way into the export market. Like any business, we want to diversify our markets so the company is not reliant on any one region for all of its revenues. And, like any business, we want to realize the highest value for our resource. 
In $2002,20 \%$ of our $\log$ sales volume went to Asia, $21 \%$ to the US, and 59\% was sold here in BC. Had we not had this diversification, more than half our loggers and many of our contractors would have been out of work and we would have ended up on the same flight path as Air Canada.

\section{Log Exports}

Log exports is an issue that affects more than TimberWest and our employees. It impacts the property rights and timber values of more than 20000 private forest owners in BC, including many families who have owned forest land for generations. The restrictions on private forest land also cost the Province millions of dollars in lost stumpage and tax revenues.

The restrictions are also an irritant in the US/Canada softwood lumber trade dispute because they clearly transfer value from the tree growers to manufacturing companies, allowing sawmills on the coast of BC to enjoy lower raw material costs than they would experience in the absence of such restrictions.

$\mathrm{BC}$ is the only province in Canada where the federal government prevents private forest landowners from selling their $\operatorname{logs}$ into the market of their choice. This despite the fact that, in the absence of similar restrictions in all other provinces, Canada is a net importer of logs, generally importing four times more logs annually than it exports.

While it is counterintuitive, lifting the restrictions would ultimately result in lower export volumes. That is because domestic log prices would move closer to international market levels, reducing the economic incentive to export.

\section{The Coastal Forest Industry}

Enough about private timberland for the moment; let's move on to talk about public land and the situation the coastal forest industry finds itself in today. I am going to be fairly candid in my remarks because, given the state of things, this is not the time for sugar-coating the situation and pretending the industry is not in serious trouble.

The fact is, the public land logging and sawmilling industry on the coast has been spiralling downwards for many, many years. No matter which economic trend, or indicator, you wish to look at - be it lumber production, harvest levels, employment, investment, market share, capital utilization, earnings or return on capital employed-you cannot help but conclude that the public lands business on the coast is on its back, it is badly broken, and the status quo is no longer an option.

A more accurate analogy is that the industry is in the critical care ward, requiring major surgery to survive. And were it not for a favourable exchange rate and the presence of highvalue cedar on the coast we would have gone directly to the morgue some time ago.

You might ask why the CEO of a high-performing company cares, since two-thirds of our harvest and even more of our profit comes from private, not public, lands. Well, I care for three reasons; one is personal and two are business-related.

On the personal side, I find it disturbing as a British Columbian to see that we have the best timber in the world, on the one hand, but are witnessing the ongoing loss of employment and investment on the other. This has had a devastating impact on individuals and communities. It is also regrettable to see the consequent loss of revenues to the Crown, since the wealth created in this industry sector could help in a more meaningful way to pay for schools, hospitals and other important public services. Trees should provide the same economic benefit to British Columbians that oil and gas provides to Albertans.

On the business side, I care because while TimberWest's Crown harvest is indeed only one-third of our annual cut, at 1.2 million $\mathrm{m}^{3}$ per year it is still significant, making us one of the four largest tenure holders on the coast. Our public lands are underperforming and it has my attention because our investors are looking for a commercial return on the funds they have entrusted to management.

The other business reason for my concern, which I will return to later in my remarks, is that our private timberland business in $\mathrm{BC}$ needs a robust, competitive, sawmilling industry on the coast for it to realize its full potential. The fact that we do not have a vibrant processing industry nearby impairs the value of our private lands. It is one reason why stumpage values in $\mathrm{BC}$ are lower than those south of the border in Washington and Oregon.

My analysis of the situation suggests that the coastal industry has failed for two sets of reasons. The first relates to external factors and these include the fact that principal end-markets like Japan softened considerably with the Asian economic crisis in 1997, and have yet to recover. At the same time, Japanese customers are changing their preferences and moving away from green products, which the coast produces more of than anything else, to dry products. Competition has become much more intense in recent years with new entrants from other regions around the world. This has placed downward pressure on prices. Product substitution has increased, and so on.

So, there were clearly external issues related to products, markets and competition. I cannot help but think, however, that any business is up against a constantly changing external environment. Who in this room can say that his/her industry is insulated from these types of external changes? It seems to me one of the elements that separates the winners from the losers is how well they anticipate and adapt to such changing business conditions.

Which brings me to the second set of factors why our coastal industry has failed. These are internal in nature, and of our own making, and I believe they played a more profound role in the coast's demise. I say so because they inhibited the required responses to our changing external circumstances. In a nutshell, the problem underlying most of our ills is that government was and is too involved with our industry, both from an ownership point of view and as its regulator. As they know in baseball, you cannot be both a pitcher and an umpire.

No doubt well intended, and perhaps even appropriate long ago, provincial government policies like appurtenancy, cut control, minimum processing requirements and others, led to a set of entitlements over time for licensees, labour and contractors. The unfortunate outcome was that costs increased while industry competitiveness and flexibility decreased. We had and continue to have a centrally planned and controlled forest industry where government stipulated harvest levels, irrespective of market conditions; government directed fibre flows to specific sawmills, regardless of whether logs were going to their highest and best use; government had a veto over tenure transfers (and when it did approve them it kept $5 \%$ of the AAC); government dictated who had exclusive rights to harvest timber; government introduced a costly, process-driven set of regulations prescribing in great detail how to harvest the resource, and so on. 
The Forests Minister did a great job of describing this when he appeared at the Board of Trade a few weeks ago. It was social engineering in its purest form and, like most attempts at social engineering worldwide, it failed. What was thought to be good public policy for workers and communities turned out to be their death knell because the coastal industry has become the highest-cost jurisdiction in the world, it continues to lose market share, and, as a result of its deteriorating financial condition and profitability, it has been starved of both sustaining and growth capital. Logs are getting smaller and more secondgrowth harvest is coming on stream. The reality is that we do not have the machinery and equipment in place today to process these logs efficiently.

The federal government had a hand to play in this social engineering as well, by restricting private land log exports in BC. Like the provincial regulations, it was thought to be good public policy for workers and communities. We fell into the trap of believing the simplistic notion that exporting logs was equivalent to exporting jobs. The reality is that forcing private landowners to sell their logs to domestic sawmills at below-market prices does not foster a globally competitive industry. It does not save jobs. But it does discourage many small private owners from investing and harvesting in their lands because of the weak prospect for returns.

So how do we get out of the critical care ward and into a healthier space?

I believe the industry needs to do three things: it must rationalize and get smaller; it must get costs down; and it must improve the utilization of both human and capital resources. The IWA, Bill 13 contractors (who have guaranteed harvesting rights for half of the Crown harvest) and licensees each have a role to play in making this happen. If they rise to the challenge, the resulting positive impact will register on financial statements and the industry will attract the new capital so badly required to modernize existing facilities and construct new ones. This will create new jobs and economic prosperity. If they do not rise to the challenge, new entrants will replace them.

While private sector industry participants must change, governments at both provincial and federal levels must also change by removing barriers and creating the policy environment that enables the required restructuring. That is to say, they have to abandon the social engineering of the past and embrace a set of reforms where market forces drive timber prices, market forces drive government stumpage revenues, and market forces drive timber-harvesting fees.

Last week, the government of $\mathrm{BC}$ announced a suite of policy changes that moves us in this direction. While we are concerned about transitional issues and the details that have to follow, TimberWest is very supportive of these changes and we congratulate Premier Campbell and his government.

We also think it is imperative for the federal government to follow BC's lead and do its bit to allow free market forces into the industry. At last week's PWC forestry conference in Vancouver, Doug Waddell, Assistant Deputy Minister to Pierre Pettigrew, said the federal government would rescind its restrictions on the export of logs from privately owned land in BC as part of a trade deal on softwood lumber with the US. In light of the policy changes that $\mathrm{BC}$ has just announced, the federal government should be removing its restrictions now. The province did not link the timing of its policy reforms to a trade deal, even though its new market-based policies could have been used as a bargaining chip to achieve free trade in lumber. The Federal Government should not either.

\section{Forest Ownership}

My remarks thus far have been about government forest policy. I will now shift gears and discuss forest ownership. Clearly, the policy changes are a step in the right direction, but by themselves, they are not going to guarantee the future competitiveness of the $\mathrm{BC}$ industry or ensure that the Province realizes the full economic potential of its forests.

The framework the Province set out last week for First Nations could lead to an equitable settlement of aboriginal issues. This could pave the way for considering the alternative of private sector ownership of at least some of our forest lands.

Everyone in this room likely agrees that that the free enterprise system works. In centrally controlled economies, people's savings can only be invested in government securities. What makes the free enterprise system unique is the ability people have to invest their savings in other assets, including profitable commercial enterprises. In our modern, sophisticated economy, investors, and not the government, determine how people's savings are put to use. This is the main reason that a marketbased, free enterprise system works far better than any alternative.

While there is certainly a need for government to have an ownership position in things like hospitals, schools, transportation infrastructure and essential public services, I subscribe to the view that if government does not have to be in a particular sphere of economic activity, then it should disengage, because the private sector has demonstrated it will always produce better long-term results for all stakeholders.

Government owns $95 \%$ of the forest land in BC. One has to ask whether the public interest is better served by having a centrally planned ownership model for our forests, or a free enterprise ownership model.

Canada is one of the very few countries in the world where almost all commercial forests remain publicly owned. Threequarters of Scandinavian timberland is privately owned. Forests in Western Europe, Chile, Brazil, New Zealand, and Australia are also privately owned. And, of course, there is the United States, our biggest customer and our biggest competitor. Its timberland is $70 \%$ privately owned.

Who has it right? Is it us or the rest of the world? I suggest that the rest of the world has it right and $\mathrm{BC}$ is the outlier. Let me explain my reasoning, but first let me make sure you understand my position on the main concerns the public has when evaluating the merits of private ownership of $\mathrm{BC}$ timberland.

Government can assure safety and environmental standards are met without owning the asset. Let me give you two reasons why this is true.

First, the government already does this very effectively on two-thirds of TimberWest's harvest, which is on our private land. We and other private land owners worked together with provincial government agencies for more than three years to design and implement a results-oriented regulatory approach for harvesting private lands that protects environmental values and includes public oversight. And managed forest owners have demonstrated that they can protect the environment. Private land practices are subject to independent third-part audits and we have had successful results from the Land Reserve Commission and Fisheries and Oceans Canada audits. 
Second, and as further proof, the government has not found it necessary to maintain ownership positions in oil and gas companies, railways, and so on, to achieve its public policy goals. The necessary safeguards worked in these industries, and it works in forestry as well.

The Province does not lose control over commercial timberland just because it is in private hands. The government will continue to have an important role to play as a regulator protecting the public interest. In fact, selling commercial timberland could allow the government to do an even better job of regulating because it removes the inherent conflict of interest that comes when government is both landlord and regulator. We find it interesting that government-managed lands have forest practices code violations more frequently than industry-managed lands. This proves just how difficult it is for anyone to be the pitcher and the umpire in a baseball game.

Having accepted the fact that government will continue to regulate things like safety, environmental stewardship and employment standards, let me get back to my main point. The evidence from other jurisdictions points to the fact that private forest ownership is a more effective model, resulting in a more competitive and profitable industry. In turn, profitable businesses produce more value for employees, communities and the province.

There are, no doubt, more than five reasons why more private timberland ownership would be beneficial in British Columbia, but I will stop at five.

First, private ownership will result in commercially driven decision-making, uncompromised by political considerations. Business and politics are not a good mix. A good example of how political considerations result in poor business decisions in this industry is the previous government's acquisition of $50 \%$ of the equity of Skeena. Or, in a different BC industry, the decision to design and build our own fast ferries.

I can also tell you from first-hand experience as CEO of a commercial Crown corporation in this province for more than 10 years - and Crown corporations are supposed to be further removed from government than any ministry-every time the minister responsible changed, or the government changed, it provided a fresh opportunity for competitors, labour unions, suppliers and sometimes even customers to lobby government to attempt to undermine commercial decisions.

It is difficult for government to resist the special interests clamouring for exemptions from the market. And while this Liberal Government may hold the line, future governments may not.

The second benefit of private ownership is that it will result in much greater investments in the land base. Renters have no incentive to make long-term capital investments, nor are governments because they have too many more immediate demands-like funding hospitals and schools. Only private owners make the necessary investments in the land base to increase returns.

At TimberWest, for example, we invest considerable sums of money on our private land for improved inventory information, to increase the growth rate of our trees and on research that will yield future growth rate gains. We expect a return well in excess of our cost of capital. But we require certainty of ownership to make such investments because they are long-term in nature. On our Tree Farm Licenses, however, we do what we are told; no more and no less. The recent policy reforms do not provide the framework to invest for the long term.
Third, the private sector will do more with less, reducing the footprint of industry. Selling commercial timberland would only involve a small fraction of the Provincial land base- - the limited portion that is suitable for commercial forestry. For the most part, we are talking about the valley bottoms. The areas best suited for commercial forestry have already been logged and are now growing stands of second growth.

Moving to a private timberland model will get logging out of increasingly sensitive areas such as the mid-coast. So the more productive nature of private forestry means the footprint of the industry can be reduced yet the same or more value will be produced. The Province does not have to privatize areas that have special attributes that need preserving for future generations. (Further, $12.52 \%$ of the province is already protected in Provincial parks, recreation areas and ecological reserves. To put that in perspective: that's two-and-a-half times the size of Switzerland.)

Fourth, more revenue would accrue to government with private ownership, allowing it to either reduce debt or provide additional services. The rapid rise of logging costs on public lands in $\mathrm{BC}$, in combination with increased international competition, has reduced harvests substantially in many parts of the province. The result is that companies have shut down operations in many areas and jobs and tax revenue have been lost.

Private landowners, including ourselves, Weyerhaeuser and myriad small owners, have kept employees working while most Crown-dependent companies were curtailed in 2002. Private landowners have been the most steady employers and contributors to government coffers in the BC forest sector, contributing about $\$ 200$ million in direct corporate taxes and another $\$ 200$ million in employee related contributions, the latter based on a direct payroll of over half a billion dollars.

TimberWest, which owns less than $2 \%$ of forest land in BC, is worth almost one billion dollars. So while we can only estimate, we think the sale of some land on the Coast alone could raise billions. Given the Province's debt load, privatization would go a long way to reducing future interest expense.

Private timberland owners could easily double or triple the value the Province is receiving from its forest resource. On our private timberlands, we generate a margin of approximately double that of the average stumpage the Government receives on the Coast (and that is before deducting the costs of operating the Ministry of Forests). And timberland owners in Washington State receive triple the value because a competitive sawmilling and logging industry exists.

Fifth, regarding the endless series of trade disputes with the US on softwood lumber, it is worth noting that in the Maritimes, in excess of $50 \%$ of the forests are privately owned. As such, the US exempts that region of the country from countervailing duties. So privatizing our forests also gets us trade peace. How can the Americans argue there are government subsidies if government no longer owns the resource?

So, to me, all of the foregoing suggests that we have to privatize some, if not all, of our commercial forests as we resolve our Aboriginal issues.

Of course, the compelling question is: can we do this in $\mathrm{BC}$ ?

Most British Columbians, including many who work in the industry, think the public will be hostile to even a partial privatization of our forests. That pre-supposes that the public is unwilling to try new approaches or to fairly consider what has worked in other jurisdictions and in other industries in this 
jurisdiction. New Zealand and Australia have both privatized, or issued leases that confer private property-like rights on timberland.

I believe it is possible to create win-wins in BC forests. But it requires freeing ourselves of outmoded prejudices and fears, breaking free from all of the self-imposed barriers that prevent us from becoming what we want to become. It means being willing to compete without the "protection" of the government because we are confident in our ability to be successful.

I have covered some emotional topics this afternoon. I hope that someday soon people will be able to set emotion aside and logically look at how we can get the best and most sustainable value from our forest resource.

As the largest owner of private land in BC, TimberWest has first-hand knowledge and a unique perspective on the benefits of private sector ownership of forest land.

Getting the most value will translate into more stable jobs for communities. Companies will be positioned to attract investment and be able to grow, and more wealth will be created for all, including our government-funded hospitals and schools.

And all of that is in the best interest of everyone in this province. 